\title{
A Facile Synthesis of CuBi204 Hierarchical Dumbbell-Shaped Nanorods Cluster: A Promising Photocatalyst for the Degradation of Caffeic Acid
}

Mohammad Ashfaq ( $\square$ mohdashfaqbiotech@gmail.com )

BS Abdur Rahman University: B S Abdur Rahman Crescent Institute of Science \& Technology

https://orcid.org/0000-0003-2644-6783

Neetu Talreja

University of Concepción: Universidad de Concepcion

Divya Chauhan

University of South Florida

Carlos Anibal Rodríguez

University of La Serena: Universidad de La Serena

Adriana Consuelo Mera

University of La Serena: Universidad de La Serena

Ramalinga Viswanathan Mangalaraja

University of Concepción: Universidad de Concepcion

\section{Research Article}

Keywords: CuBi204, photocatalyst, caffeic acid, phenolic compounds.

Posted Date: January 17th, 2022

DOl: https://doi.org/10.21203/rs.3.rs-719635/v1

License: (c) (i) This work is licensed under a Creative Commons Attribution 4.0 International License.

Read Full License

Version of Record: A version of this preprint was published at Environmental Science and Pollution Research on March 16th, 2022. See the published version at https://doi.org/10.1007/s11356-022-195922. 


\section{Abstract}

The present study focuses on synthesizing Cu-bismuth oxide $\left(\mathrm{CuBi}_{2} \mathrm{O}_{4}\right)$ based nanorods by using a simple co-precipitation method for the photocatalytic degradation of caffeic acid (CA). Incorporating $\mathrm{Cu}$ metal ions during the synthesis of $\mathrm{CuBi}_{2} \mathrm{O}_{4}$ nanorods might be advantageous to avoid aggregation and control the leach out of metal ions. The calculated bandgap values of $~ 1.04,1.02$, and $0.94 \mathrm{eV}$ were observed for $\mathrm{CuBi}_{2} \mathrm{O}_{4}$ with different amounts of $\mathrm{Cu} 1.0,0.50$, and $0.25 \mathrm{~g}$, respectively. Varying quantities of $\mathrm{Cu}$ metal ions easily tuned the bandgap value within the $\mathrm{CuBi}_{2} \mathrm{O}_{4}$ based nanorods. However, a further decrease in the bandgap value increased the recombination rate; less photocatalyst performance was observed. The $\mathrm{Cu}$ within the $\mathrm{CuBi}_{2} \mathrm{O}_{4}$ based nanorods changed the electronic properties as well as the antibacterial ability. Therefore, the synthesized $\mathrm{CuBi}_{2} \mathrm{O}_{4}$ based nanorods cluster might be a promising material for the photocatalytic degradation of CA.

\section{Introduction}

Phenolic compounds such as caffeic acid (CA), ferulic acid (FA), gallic acid (GA), rosmarinic acid (RA), and chlorogenic acid, etc., are a class of compounds that are essential to humans and plants. Particularly, CA, FA, GA, RA, and chlorogenic acid have several biological and chemical properties such as antioxidant, chelating tendency with metals, good scavengers for oxygen species, and electrophiles, thereby having the potential ability to modify various enzymatic activities. Among all of them, CA acts as a significant component mainly for plant biomass and also an intermediate in lignin biosynthesis (Khuwijitjaru et al. 2014, Medina et al. 2012, Ozturk et al. 2012, Villegas et al. 2016). CA is considered an important human, environmental, and socio-economic development despite several advantages of the phenolic compounds. However, the presence of a large amount of CA in the wastewater leads to a negative impact on the environment, subsequently, human and animal health. Olive milling discharge contains a high amount of $\mathrm{CA}$, and its disposal is one of the significant challenges nowadays for environmental and agronomical aspects. $C A$ is mainly responsible for the high value of chemical oxygen demands (COD) that reduce the dissolved oxygen, thereby detrimental health effects on aquatic life. CA has unusual antimicrobial activity, a carcinogen, and phytotoxic ability; thereby, CA compounds developed resistance to the biological degradation that leads to infertility of soils and groundwater contamination and detrimental effects on human health (Anwar et al. 2012, Bai et al. 2014, Capasso et al. 1995, Espíndola et al. 2019, Hernandez \&Edyvean 2018, Iwahashi 2015, Magnani et al. 2014, Venditti et al. 2015). In this context, numerous materials need to be synthesized to remove CA compounds from the water.

In the last few decades, various processes like coagulation, adsorption, co-precipitation, and reverse osmosis have been applied to remove CA contamination from the wastewater. However, relatively lesser removal efficiency and higher cost limit their applicability towards end applications. Moreover, the photocatalytic efficiency also depends on the types of materials and pollutants (Khulbe \&Matsuura 2018, Talreja et al. 2014). In this perspective, the photocatalytic process has a significant advantage over many 
physical methods that can destroy contaminants. The photocatalytic process has the potential ability due to its natural energy utilization that might be an ultimate solution for the degradation of CA from the wastewater.

The photocatalysis process becomes the most widely used method to treat the various organic and inorganic contaminants. Usually, the photocatalysis process mainly depends on the photocatalyst materials. Moreover, the photodegradation efficiency of the multiple contaminants might be increased with the help of developing the hybrid photocatalyst materials (Ajmal et al. 2014, Pawar et al. 2018). Several photocatalyst materials $\left(\mathrm{TiO}_{2}, \mathrm{C}_{3} \mathrm{~N}_{4}\right.$, layered double hydroxides $(\mathrm{LDH})$, graphene, and bismuth oxy-halides, etc.) and their hybrid materials (carbon-doped $\mathrm{TiO}_{2}$, Ce doped $\mathrm{CoOOH}$ catalyst, and $\mathrm{Cr}_{2} \mathrm{~S}_{3}-$ $\mathrm{Bi}_{2} \mathrm{O}_{3}$ ) have been developed so far for the degradation of the various contaminants (Ashfaq et al. 2021, Silva et al. 2009, Talreja et al. 2021a, Venditti et al. 2015, Yáñez et al. 2016). For example, carbon-doped $\mathrm{TiO}_{2}$ for the visible light degradation of $\mathrm{CA}$ The $\mathrm{TiO}_{2}$ sample was doped with glucose and kept inside the oven at $160^{\circ} \mathrm{C}$. The synthesized carbon-doped $\mathrm{TiO}_{2}$ based photocatalyst was mesoporous, efficiently removing CA due to the synergetic effects (both adsorption and photodegradation) (Silva et al. 2009).

Recently, the bismuth-based photocatalyst is continuously gaining attention due to its low bandgap and excellent performance in various applications such as solar cells, antibiotic activity, energy storage, and photodegradation of various organic and inorganic pollutants (Chen et al. 2020, Darkwah et al. 2019, Monfort \&Plesch 2018, Talreja et al. 2021b). The bismuth oxides or complex oxide are often used as an efficient photocatalyst due to the low bandgap, high photocatalytic activity, and high stability (Ibrahim et al. 2020, Subbarao 1962, Zhao et al. 2014). However, the relatively less degradation efficiency of contaminants still needs concern. Therefore, there is a required order to synthesize newer materials or amendments in the existing photocatalyst materials to increase photodegradation efficiency. In this aspect, the incorporation of metal ions might be advantageous that easily tune the bandgap and enhances the photodegradation efficiency.

Copper $(\mathrm{Cu})$ is extensively used in various applications like environmental remediation, energy, antimicrobial, agriculture, wound healing, and photocatalysis (Ashfaq et al. 2014, Ashfaq et al. 2016, 2017, Hassan et al. 2019, Sasidharan et al. 2021, Yoong et al. 2009). Cu has been used as a dopant material within the semiconductor materials that quickly tuned the bandgap of the materials, thereby improving the photodegradation efficiency. Usually, incorporating $\mathrm{Cu}$ into the semiconductor materials has been done by using different methods such as impregnation, deposition, and surface modification. However, the aggregation and leach-out ability lead to contamination of the environments (Aguilar et al. 2013, López et al. 2009, Slamet et al. 2005). Therefore, the incorporation of metal ions during the synthesis process might be resolved such issues associated with the simple doping process. The unique combination of bismuth oxide and $\mathrm{Cu}$ might be an effective photocatalyst for the degradation of CA.

The present study describes the synthesis of Cu-bismuth oxide $\left(\mathrm{CuBi}_{2} \mathrm{O}_{4}\right)$ based nanorods using a simple co-precipitation method for the photodegradation of CA. The incorporation of Cu metal ions within the bismuth oxide skeleton during the synthesis process of nanorods might be beneficial to avoid the 
agglomeration of metal ions and leach out within the wastewater. Moreover, the bandgap values can be easily tuned with the varying amount of $\mathrm{Cu}$ metal within the $\mathrm{CuBi}_{2} \mathrm{O}_{4}$ based nanorods. Therefore, synthesis for $\mathrm{CuBi}_{2} \mathrm{O}_{4}$ based nanorods is a facile and one-step process at room temperature applied for the degradation of CA by using solar radiation. The main aim of the present study is to develop simple, effective, and promising photocatalyst materials for the degradation of CA that offer new tools for contributing to the challenging waste disposal issue associated with the phenolic compounds, especially CA.

\section{Material And Method 2.1. Chemicals}

Bismuth nitrate pentahydrate $\left(\mathrm{Bi}\left(\mathrm{NO}_{3}\right)_{3} \cdot 5 \mathrm{H}_{2} \mathrm{O}\right)$, copper chloride $\left(\mathrm{CuCl}_{2}\right)$, nitric acid $\left(\mathrm{HNO}_{3}\right)$, sodium hydroxide $(\mathrm{NaOH})$, ethanol $\left(\mathrm{C}_{2} \mathrm{H}_{5} \mathrm{OH}\right)$, and $\mathrm{CA}$ were purchased from Sigma Aldrich, Chile. All chemicals were used for the highest grade of purity ( 99.0\%). All the solutions were prepared using Milli-Q water.

\subsection{Synthesis of $\mathrm{CuBi}_{2} \mathrm{O}_{4}$ nanorods}

Approximately $3.8 \mathrm{~g}$ of $\mathrm{Bi}\left(\mathrm{NO}_{3}\right)_{3} \cdot 5 \mathrm{H}_{2} \mathrm{O}$ was dissolved in $20 \mathrm{~mL}$ of Milli-Q water containing $2.5 \mathrm{~N}$ of $\mathrm{HNO}_{3}$ under magnetic stirring to produce a homogenous solution of $\mathrm{Bi}\left(\mathrm{NO}_{3}\right)_{3} \cdot 5 \mathrm{H}_{2} \mathrm{O}$. The produce homogenous solution of the $\mathrm{Bi}\left(\mathrm{NO}_{3}\right)_{3} \cdot 5 \mathrm{H}_{2} \mathrm{O}$ was dissolved $1 \mathrm{~g}$ of $\mathrm{CuCl}_{2}$, and the resultant solution was designated as solution $A$. The $6 \mathrm{M} \mathrm{NaOH}$ was used in $140 \mathrm{~mL}$ of water, which was defined as solution $B$. Next, solution $B$ was slowly added dropwise to solution A under constant stirring, and immediately a suspension solution was formed. The obtained suspension was continuously magnetically stirred for $12 \mathrm{~h}$ at room temperature $\left(\sim 25^{\circ} \mathrm{C}\right)$, during which a brown precipitate was gradually formed to produce $\mathrm{CuBi}_{2} \mathrm{O}_{4}$ nanorods. The produce $\mathrm{CuBi}_{2} \mathrm{O}_{4}$ nanorods were collected and washed using deionized (DI) water and $\mathrm{C}_{2} \mathrm{H}_{5} \mathrm{OH}$ several times. Next, the washed $\mathrm{CuBi}_{2} \mathrm{O}_{4}$ nanorods were kept for drying in an oven at $60^{\circ} \mathrm{C}$ for 12 $\mathrm{h}$ to obtain the final $\mathrm{CuBi}_{2} \mathrm{O}_{4}$ nanorods. Some samples of $\mathrm{CuBi}_{2} \mathrm{O}_{4}$ nanorods were also synthesized by varying the amount of $\mathrm{Cu}$ metal $(0.5 \mathrm{~g}$ and $0.25 \mathrm{~g})$ for comparison purposes. Figure 1 . shows the schematic representation of the synthesis of $\mathrm{CuBi}_{2} \mathrm{O}_{4}$ nanorods.

\subsection{Photocatalytic degradation of CA.}

The photocatalytic degradation of CA was performed using a solar simulator under xenon lamp irradiation (VIPHID $6000 \mathrm{k}, 12 \mathrm{~W} / \mathrm{m}^{2}$ ). The borosilicate glass photocatalytic reactor was filled with 250 $\mathrm{mL}$ of different concentrations $(1,5$, and $10 \mathrm{mg} / \mathrm{L})$ of the CA solution. Next, the synthesized $\mathrm{CuBi}_{2} \mathrm{O}_{4}$ nanorods as a photocatalyst were added to the reactor. The $\mathrm{CA}$ solution with $\mathrm{CuBi}_{2} \mathrm{O}_{4}$ nanorods was kept thoroughly stirred in the dark condition to achieve an adsorption-desorption equilibrium for $30 \mathrm{~min}$. The different doses $(100,200,300$, and $400 \mathrm{mg} / \mathrm{L})$ of the $\mathrm{CuBi}_{2} \mathrm{O}_{4}$ nanorods were tested. The $\mathrm{pH}$ value of the CA solution was varied from 2 to 10 . The temperature of the photocatalytic reactor was maintained at 
room temperature with the help of circulating the tap water, and continuous stirring was provided throughout the reaction process. The analysis was performed with a UV-visible spectrophotometer at 200-800 nm wavelengths.

\subsection{Characterization of $\mathrm{CuBi}_{2} \mathrm{O}_{4}$ nanorods}

The surface morphology of the $\mathrm{CuBi}_{2} \mathrm{O}_{4}$ nanorods was characterized by using field emission scanning electron microscopy (FE-SEM) analysis (MIRA3-, TESCAN, AS, Brno, Czech Republic). The elemental analysis and mapping of the $\mathrm{CuBi}_{2} \mathrm{O}_{4}$ nanorods were observed using energy dispersive $\mathrm{X}$-rays spectroscopy (EDX) analysis (Oxford, Inc., Germany). The crystal pattern and crystalline size of the $\mathrm{CuBi}_{2} \mathrm{O}_{4}$ nanorods were measured by X-ray diffraction (XRD) analysis. For the XRD pattern, $\mathrm{Cu}-\mathrm{K}_{\mathrm{a}}$ radiation $\left(K_{a}=1.54178 A^{\circ}\right)$ at a scan rate of $5^{\circ} \mathrm{C} /$ min per min was used and the range of $10-100^{\circ}$ angle. The Brunauer-Emmett-Teller (BET) surface area analysis and pore size distribution were calculated by adsorption/desorption isotherm (Autosorb-1C instrument, Quantachrome, USA). The bandgap of the $\mathrm{CuBi}_{2} \mathrm{O}_{4}$ nanorods samples was calculated by DRS analysis using UV-visible spectroscopy (Thermo scientific evolution 220). The surface functional group of the $\mathrm{CuBi}_{2} \mathrm{O}_{4}$ nanorods was analyzed by using Fourier-transform infrared (FT-IR) spectra (Bruker Tensor 27, Germany). The FT-IR spectrum was recorded with a range of $400-4000 \mathrm{~cm}^{-1}$. The sample chamber of the FT-IR was continuously purged with nitrogen gas to remove the moisture and carbon dioxide.

\section{Results And Discussion}

\subsection{Material charcterization}

\subsubsection{SEM and EDX analyses}

Figure 2 shows the SEM images and size distribution plot (nanorods diameter) of the synthesized $\mathrm{CuBi}_{2} \mathrm{O}_{4}$ nanorods-based photocatalyst material. Figure 2 (a-c) shows the $\mathrm{CuBi}_{2} \mathrm{O}_{4}$ nanorods at lower and higher magnifications, respectively. As observed from the figure, the surface was covered with the hierarchical dumbbell-shaped nanorods cluster (Fig. 2a). Figure 2 (b-c) shows the higher magnification images of the $\mathrm{CuBi}_{2} \mathrm{O}_{4}$ nanorods cluster composed of several thin hollow nanorods-like structures.

Figure 2 (d) shows nanorods diameter or size distribution plot of $\mathrm{CuBi}_{2} \mathrm{O}_{4}$ nanorods; as observed from the figures, the nanorods consist of 100-160 nm of diameter. The hierarchical dumbbell-shaped hollow nanorods cluster might increase the exposure of CA. Moreover, the hollow nanorod structures might be improved the specific surface area of the photocatalytic materials (Lee \&Kim 2019, Yuvaraja et al. 2018). Therefore, the synthesized $\mathrm{CuBi}_{2} \mathrm{O}_{4}$ hierarchical dumbbell-shaped nanorods cluster might enhance the overall removal of CA due to synergetic effects, which was further confirmed from the BET surface area and photodegradation performance. 
Fig. 3 shows elemental analysis and mapping of the synthesized $\mathrm{CuBi}_{2} \mathrm{O}_{4}$ nanorods based photocatalyst materials. As observed from the study, the presence of $\mathrm{Cu}$ metal ions confirms that the $\mathrm{Cu}$ within the $\mathrm{Bi}_{2} \mathrm{O}_{4}$ crystal and partly replaces $\mathrm{Bi}$ from the $\mathrm{Bi}_{2} \mathrm{O}_{4}$ crystal lattice. The elemental mapping of the $\mathrm{CuBi}_{2} \mathrm{O}_{4}$ ensures the $\mathrm{Cu}$ metal ions are uniformly incorporated within the $\mathrm{Bi}_{2} \mathrm{O}_{4}$ by using the co-precipitation method. Interestingly, the higher metal, around $24 \%(\mathrm{w} / \mathrm{w})$ of Cu elements observed while $22 \%$ of Bi-metal loading was seen from the image confirms the presence of $\mathrm{Cu}$ in the $\mathrm{Bi}_{2} \mathrm{O}_{4}$ crystal.

\subsubsection{XRD analysis}

The crystallinity and crystallite size of the synthesized $\mathrm{CuBi}_{2} \mathrm{O}_{4}$ nanorods were determined from the XRD spectrum. Figure 4 shows the XRD spectrum of the $\mathrm{CuBi}_{2} \mathrm{O}_{4}$ nanorods samples. As seen in the spectrum, the diffraction peaks of $\mathrm{CuBi}_{2} \mathrm{O}_{4}$ nanorods were observed at $2 \varangle$ angle of $20.99^{\circ}, 28.10^{\circ}, 29.73^{\circ}, 31.02^{\circ}$, $33.44^{\circ}, 34.58^{\circ}, 37.50^{\circ}, 46.72^{\circ}, 53.18^{\circ}, 55.61^{\circ}, 60.46^{\circ}, 66.29^{\circ}$, and $68.23^{\circ}$ which corresponded to the crystallographic indices of the (200), (211), (220), (002), (310), (112), (202), (312), (411), (213), (332), (521), (530), and (413), respectively. The diffraction pattern completely matched with the $\mathrm{CuBi}_{2} \mathrm{O}_{4}$ (JCPDS 042-0334) (Sharma et al. 2016). The average crystallite size was observed to be $21.9 \mathrm{~nm}$ for $\mathrm{CuBi}_{2} \mathrm{O}_{4}$ nanorods. The synthesized $\mathrm{CuBi}_{2} \mathrm{O}_{4}$ nanorods-based photocatalyst materials showed the pure tetragonal phase.

\subsubsection{BET surface area and pore size distribution}

Figure 5 shows the pore size distribution (PSD) of the $\mathrm{CuBi}_{2} \mathrm{O}_{4}$ nanorods. The PSD was calculated using the Barrett-Joyner-Halenda (BJH) method for mesopores $(2-40 \mathrm{~nm})$ and density functional theory (DFT) for micropores $(<2 \mathrm{~nm})$. The pore diameter for $\mathrm{CuBi}_{2} \mathrm{O}_{4}$ was $5.4 \mathrm{~nm}$ that might be sufficient to adsorb the CA molecule; thereby, photodegradation could be accomplished with adsorption on the surface of nanorods. The BET surface area of $\mathrm{CuBi}_{2} \mathrm{O}_{4}$ nanorods was calculated as $\sim 4.2 \mathrm{~m}^{2} \mathrm{~g}^{-1}$. The smaller BET surface area was due to the packed bundle of nanorods of $\mathrm{CuBi}_{2} \mathrm{O}_{4}$. Next, the total pore volume was $0.0078 \mathrm{cc} / \mathrm{g}$, and the pore diameter of $5.4 \mathrm{~nm}$ showed the presence of mesopores over the surface of $\mathrm{CuBi}_{2} \mathrm{O}_{4}$ nanorods. The mesoporous nanorods-shaped structure of $\mathrm{CuBi}_{2} \mathrm{O}_{4}$ led to proper exposure of the $\mathrm{CA}$ molecule. The degradation could be done by following the adsorption process, which is discussed later in the manuscript.

\subsubsection{FTIR analysis}

Figure 6 shows the FT-IR spectrum to analyze the functional group on the surface of $\mathrm{CuBi}_{2} \mathrm{O}_{4}$ nanorodsbased photocatalytic material. The primary characteristic peaks of $\mathrm{CuBi}_{2} \mathrm{O}_{4}$ nanorods were observed at 497, 1398, and $1660 \mathrm{~cm}^{-1}$ and were assigned to the $\mathrm{Cu}-\mathrm{O}$, Bi-O, and $\mathrm{H}_{2} \mathrm{O}$ bending modes of $\mathrm{CuBi}_{2} \mathrm{O}_{4}$ nanorods, respectively. Some peaks were also observed at $3180 \mathrm{~cm}^{-1}$ and $3480 \mathrm{~cm}^{-1}$ refer to the $\mathrm{O}-\mathrm{H}$ bond stretching vibration of $\mathrm{H}_{2} \mathrm{O}$ in $\mathrm{CuBi}_{2} \mathrm{O}_{4}$ nanorods (Salehi et al. 2017). The FT-IR analysis confirmed that the $\mathrm{CuBi}_{2} \mathrm{O}_{4}$ nanorods were successfully synthesized, which has been already from the elemental analysis, elemental mapping, and the XRD studies, which are discussed earlier in the manuscript. 


\subsection{Photocatalytic performance}

$\mathrm{CuBi}_{2} \mathrm{O}_{4}$ nanorods-based photocatalytic materials were used for photocatalytic performance with an initial concentration of $10 \mathrm{mg} / \mathrm{L}$ of CA. Various parameters such as reaction time, catalytic dose, and $\mathrm{pH}$ of the solution on CA degradation yield were evaluated. The photocatalytic degradation of CA using $\mathrm{CuBi}_{2} \mathrm{O}_{4}$ nanorods-based materials was assessed at a different time interval (0 to $60 \mathrm{~min}$ ). The degradation (\%) of CA was calculated by decreasing sample absorbance from the absorbance of the standard CA.

Figure 7 shows the photocatalytic performance of the $\mathrm{CuBi}_{2} \mathrm{O}_{4}$ nanorods-based materials against the $\mathrm{CA}$ compound. Figure 7 a shows the degradation (\%) of $\mathrm{CA}$ using $\mathrm{CuBi}_{2} \mathrm{O}_{4}$ nanorods-based materials with varying amounts of $\mathrm{Cu}$ metal within the $\mathrm{CuBi}_{2} \mathrm{O}_{4}$ at $10 \mathrm{mg} / \mathrm{L}$ initial concentration. As observed from the figure, the photocatalytic degradation increased with the $\mathrm{Cu}$ metal within the $\mathrm{CuBi}_{2} \mathrm{O}_{4}$. $\mathrm{A}$ maximum of $58 \%$ degradation of CA was observed at $\mathrm{CuBi}_{2} \mathrm{O}_{4}$ nanorods ( $1.0 \mathrm{~g}$ of $\mathrm{Cu}$ metal within the $\mathrm{CuBi}_{2} \mathrm{O}_{4}$ ). The high degradation (\%) efficiency of $\mathrm{CuBi}_{2} \mathrm{O}_{4}$ nanorods ( $1.0 \mathrm{~g}$ of $\mathrm{Cu}$ metal within the $\mathrm{CuBi}_{2} \mathrm{O}_{4}$ ) was observed due to the average bandgap that enhanced the photo adsorption ability and less recombination rate. Interestingly, the $\mathrm{Cu}$ metal within the $\mathrm{CuBi}_{2} \mathrm{O}_{4}$ might play an essential role in the photodegradation of $\mathrm{CA}$. Therefore, $\mathrm{CuBi}_{2} \mathrm{O}_{4}$ nanorod with $1 \mathrm{~g}$ of the $\mathrm{Cu}$ metal within the $\mathrm{CuBi}_{2} \mathrm{O}_{4}$ was used for further study.

Figure $7 \mathrm{~b}$ shows the UV-vis spectra of $\mathrm{CA}$ using $\mathrm{CuBi}_{2} \mathrm{O}_{4}$ nanorods-based photocatalyst materials at a different time (0-60 $\mathrm{min}$ ) exposure of UV light irradiation. As observed from the figure, the absorbance of CA or peak of CA decreased with increasing the irradiation time. After 40 min of the irradiation time, the degradation or absorbance or reduction of peak became stable and reached the maximum value $(58 \%)$ within the 60 min of irradiation time.

Figure 7c the degradation (\%) with time at different concentrations of CA compounds. As observed from the figure, the degradation (\%) decreased with increasing the engagement of CA. A maximum of $95.8 \%$ and a minimum of $58 \%$ degradation were observed at 1 and $10 \mathrm{mg} / \mathrm{L}$, respectively. The data suggested that the synthesized $\mathrm{CuBi}_{2} \mathrm{O}_{4}$ nanorods have high photocatalytic performance at $1 \mathrm{mg} / \mathrm{L}$ of the CA solution. According to the US. Environmental Protection Agency (EPA) less than $1 \mathrm{ppb}$ of phenolic compounds like CA is safe for drinking water.

Figure $7 \mathrm{~d}$ shows the decrement in the dimensionless concentration $\left(\mathrm{C} / \mathrm{C}_{0}\right)$ of $\mathrm{CA}$ using synthesized $\mathrm{CuBi}_{2} \mathrm{O}_{4}$ nanorods as a function of irradiation time. The degradation of CA increased with the time of irradiation, as observed from the figure. The degradation (\%) of CA was higher at lower concentrations (1 $\mathrm{mg} / \mathrm{L}$ of $\mathrm{CA}$ ) attributed to the photocatalytic surface of reactive sites might be blocked, thereby less generation of hydroxyl radical at a higher concentration or less degradation efficiency of CA(Le Person et al. 2013). 
Based on the data described above, there are some salient observations made that enhanced the photocatalytic performance of $\mathrm{CA}$ using $\mathrm{CuBi}_{2} \mathrm{O}_{4}$ nanorods: (1) synthesis of mesoporous $\mathrm{CuBi}_{2} \mathrm{O}_{4}$ hierarchical dumbbell-shaped nanorods cluster, (2) the Cu metal incorporation within the $\mathrm{CuBi}_{2} \mathrm{O}_{4}$ nanorods, (3) narrow bandgap of $\mathrm{CuBi}_{2} \mathrm{O}_{4}$ nanorods, and (4) the $\mathrm{Cu}$ metal incorporation might augment the formation of oxygen vacancy defects (Rao et al. 2019).

Table. 1 shows the bandgap value and degradation (\%) efficiency of $\mathrm{CuBi}_{2} \mathrm{O}_{4}$ nanorods-based photocatalytic material with varying amounts of $\mathrm{Cu}$ metal. The bandgap of $\mathrm{CuBi}_{2} \mathrm{O}_{4}$ nanorods with different amounts of Cu metal $(1.0,0.50$, and $0.25 \mathrm{~g})$ was calculated to be approximately $1.04,1.02$, and $0.94 \mathrm{eV}$, respectively. The bandgap value decreased with the amount of Cu metal within the $\mathrm{CuBi}_{2} \mathrm{O}_{4}$. $\mathrm{The}$ data suggested that the bandgap value was easily tuned by changing the amount of $\mathrm{Cu}$ metal within the $\mathrm{CuBi}_{2} \mathrm{O}_{4}$. The decrement of bandgap value might be improved the recombination rate; thereby, degradation efficiency was decreased. Numerous studies suggested that incorporating Cu metal or increasing the Cu metal increased/decreased the bandgap value (Aguilar et al. 2013, Yoong et al. 2009). Therefore, the prepared $\mathrm{CuBi}_{2} \mathrm{O}_{4}$ nanorods-based photocatalytic materials might be a promising material for the degradation of CA compounds from the wastewater.

Table 1

The bandgap value of $\mathrm{CuBi}_{2} \mathrm{O}_{4}$ nanorods (with varying amounts of $\mathrm{Cu}$ metal) and its effect on degradation efficiency.

\begin{tabular}{|c|c|c|}
\hline Photocatalyst materials & Bandgap (eV) & Degradation (\%) at $10 \mathrm{mg} / \mathrm{L}$ \\
\hline $\mathrm{CuBi}_{2} \mathrm{O}_{4}-1 \mathrm{~g}$ & 1.04 & 58 \\
\hline $\mathrm{CuBi}_{2} \mathrm{O}_{4}-0.5 \mathrm{~g}$ & 1.02 & 49.3 \\
\hline $\mathrm{CuBi}_{2} \mathrm{O}_{4}-0.25 \mathrm{~g}$ & 0.94 & 32.9 \\
\hline
\end{tabular}

Figure 8a shows the degradation (\%) of $\mathrm{CA}$ at different $\mathrm{pH}(2-8)$ of the CA solution. As observed from the figure, the degradation (\%) of CA increased with the $\mathrm{pH}$ of the CA solution. Similarly, the degradation (\%) of CA increased with the irradiation time. The maximum $78 \%$ degradation was observed at $\mathrm{pH} 8$, whereas the lowest $31 \%$ degradation was observed at $\mathrm{pH} 3$. The data suggested that the surface charge of $\mathrm{CA}$ and $\mathrm{CuBi}_{2} \mathrm{O}_{4}$ nanorods photocatalyst material was the dominant factor for the degradation of the CA mechanism.

Radical scavenger capture experiments were also carried out. Figure 8b shows the radical capture experiments. The ethylenediaminetetraacetic acid (EDTA), isopropyl alcohol (IPA) and p-benzoquinone (BQ) were adopted as $\mathrm{h}^{+}$, hydroxyl radical $(\cdot \mathrm{OH})$, and superoxide radical $\left(\cdot \mathrm{O}_{2}{ }^{-}\right)$respectively; it was observed from the data that maximum degradation was achieved with no scavenger. The addition of IPA and BQ. were not exhibiting any significance on CA degradation. However, on adding EDTA, $\mathrm{h}^{+}$ 
concentration increases in the solution, which subsequently increases the degradation of CA (Zheng et al. 2019).

Figure 9 shows the two possibilities for degradation, (1) vinyl catechol (2) protocatechuic acid. Usually, the expected product is vinyl catechol formed after the first deprotonation from the $\mathrm{COOH}$ functional group occurred during the first pKa1. CA degradation could be explained based on species distribution. The CA pKa was mainly located between $\mathrm{pKa}_{1}$ and $\mathrm{pKa}_{2}$, which were 4.43 and 8.6. During the first degradation, deprotonation occurred from - $\mathrm{COOH}$ functional group to form $\mathrm{CA}_{2}$ - species (loss of two protons from $\mathrm{CA}$ ), that generate hydroxyl radical which further acted as an oxidizing agent for CA The $\mathrm{pKa}_{2}$ of $\mathrm{CA}$ was around 8.6 suggesting the second degradation occurred from the catechol group to form anionic species, which was attracted by the surface of the CuBi2O4 nanorods and further increased the degradation percentage of $\mathrm{CA}$ The $\mathrm{Cu}(\mathrm{II})$ ions also have a promoter effect on the degradation of $\mathrm{CA}$ as they enhanced the positive surface charge over the catalyst surface (Abdelkader et al. 2015, Elaziouti et al. 2015, Le Person et al. 2013). Therefore, the degradation of CA was higher at a pH value of $\sim 8$, which was also confirmed from the $\mathrm{pH}$ study discussed earlier in the text.

\section{Conclusion}

In this study, efficient $\mathrm{CuBi}_{2} \mathrm{O}_{4}$ nanorods were synthesized through a simple co-precipitation method. The SEM images showed that nanorods were packed together to form a dumbbell-shaped hollow structured cluster. The synthesized nanorods were further tested for the CA degradation in the wastewater. The XRD showed that the $\mathrm{Cu}$ partly replaced the $\mathrm{Bi}$ atom from $\mathrm{Bi}_{2} \mathrm{O}_{4}$. The DRS calculation was used to determine the bandgap of $\mathrm{CuBi}_{2} \mathrm{O}_{4}$, and the lowest bandgap value was $0.94 \mathrm{eV}$, which suitably degraded the $\mathrm{CA}$. The maximum degradation using $\mathrm{CuBi}_{2} \mathrm{O}_{4}$ nanorods was $95.8 \%$ at $1 \mathrm{ppm}$ of the CA concentration, while $58 \%$ was achieved using $10 \mathrm{ppm}$. Further, three different amounts of $\mathrm{Cu}$ within the $\mathrm{CuBi}_{2} \mathrm{O}_{4}$ were used to determine the effect of photocatalyst over the photodegradation of the $\mathrm{CA}$, and it was found that $1 \mathrm{~g} \mathrm{Cu}$ metal within the $\mathrm{CuBi}_{2} \mathrm{O}_{4}$ nanorods was the best amount to degrade $\mathrm{CA}$ from the wastewater. Additionally, the $\mathrm{pH}$ study was done for the prediction of the mechanism. A proposed CA degradation pathway was given based on the $\mathrm{pH}$. Therefore, the synthesis of $\mathrm{CuBi}_{2} \mathrm{O}_{4}$ nanorods is facile, and these nanorods are promising photocatalyst materials or options further to develop the visible-light-driven for the degradation of $\mathrm{CA}$.

\section{Declarations}

\section{Acknowledgment}

The authors acknowledge the financial support of ANID, the Government of Chile, through FONDECYT project No. 3190515 and 3190581.

\section{Conflict of Interest}


The authors have no conflict of interest.

\section{Ethical Approval}

Not applicable

\section{Consent to Participate}

Not applicable

\section{Consent to Publish}

Not applicable

\section{Authors Contributions}

M.A \& N.T design, performed experiments and writing the manuscript. D.C draws the figures, writing the manuscript and performs some characterizations. C.A.R \& A.C.M provides lab facilities to conduct research. R.V.M revised the manuscript.

\section{Availability of data and materials}

The materials were available subject to availability.

\section{References}

1. Abdelkader E, Nadjia L, Ahmed B (2015): Preparation and characterization of novel CuBi204/SnO2 $p-n$ heterojunction with enhanced photocatalytic performance under UVA light irradiation. Journal of King Saud University - Science 27, 76-91

2. Aguilar T, Navas J, Alcántara R, Fernández-Lorenzo C, Gallardo JJ, Blanco G, Martín-Calleja J (2013): A route for the synthesis of $\mathrm{Cu}$-doped $\mathrm{TiO} 2$ nanoparticles with a very low band gap. Chemical Physics Letters 571, 49-53

3. Ajmal A, Majeed I, Malik RN, Idriss H, Nadeem MA (2014): Principles and mechanisms of photocatalytic dye degradation on $\mathrm{TiO} 2$ based photocatalysts: a comparative overview. RSC Advances 4, 37003-37026

4. Anwar J, Spanevello RM, Thomé G, Stefanello N, Schmatz R, Gutierres J, Vieira J, Baldissarelli J, Carvalho FB, da Rosa MM, Rubin MA, Fiorenza A, Morsch VM, Schetinger MRC (2012): Effects of caffeic acid on behavioral parameters and on the activity of acetylcholinesterase in different tissues from adult rats. Pharmacology Biochemistry and Behavior 103, 386-394

5. Ashfaq M, Khan S, Verma N (2014): Synthesis of PVA-CAP-based biomaterial in situ dispersed with Cu nanoparticles and carbon micro-nanofibers for antibiotic drug delivery applications. Biochemical Engineering Journal 90, 79-89 
6. Ashfaq M, Verma N, Khan S (2016): Copper/zinc bimetal nanoparticles-dispersed carbon nanofibers: A novel potential antibiotic material. Materials Science and Engineering: C 59, 938-947

7. Ashfaq M, Verma N, Khan S (2017): Carbon nanofibers as a micronutrient carrier in plants: efficient translocation and controlled release of Cu nanoparticles. Environmental Science: Nano 4, 138-148

8. Ashfaq M, Talreja N, Chauhan D, Rodríguez CA, Mera AC, Mangalaraja RV (2021): A novel bimetallic (Fe/Bi)-povidone-iodine micro-flowers composite for photocatalytic and antibacterial applications. Journal of Photochemistry and Photobiology B: Biology 219, 112204

9. Bai H, Liu R, Chen H-L, Zhang W, Wang X, Zhang X-D, Li W-L, Hai C-X (2014): Enhanced antioxidant effect of caffeic acid phenethyl ester and Trolox in combination against radiation induced-oxidative stress. Chemico-biological interactions 207, 7-15

10. Capasso R, Evidente A, Schivo L, Orru G, Marcialis MA, Cristinzio G (1995): Antibacterial polyphenols from olive oil mill waste waters. J Appl Bacteriol 79, 393-8

11. Chen P, Liu H, Cui W, Lee SC, Wang La, Dong F (2020): Bi-based photocatalysts for light-driven environmental and energy applications: Structural tuning, reaction mechanisms, and challenges. EcoMat 2, e12047

12. Darkwah WK, Adormaa BB, Christelle Sandrine MK, Ao Y (2019): Modification strategies for enhancing the visible light responsive photocatalytic activity of the BiPO4 nano-based composite photocatalysts. Catalysis Science \& Technology 9, 546-566

13. Elaziouti A, Laouedj N, Bekka A, Vannier R-N (2015): Preparation and characterization of $p-n$ heterojunction $\mathrm{CuBi} 2 \mathrm{O} 4 / \mathrm{CeO} 2$ and its photocatalytic activities under UVA light irradiation. Journal of King Saud University - Science 27, 120-135

14. Espíndola KMM, Ferreira RG, Narvaez LEM, Silva Rosario ACR, da Silva AHM, Silva AGB, Vieira APO, Monteiro MC (2019): Chemical and Pharmacological Aspects of Caffeic Acid and Its Activity in Hepatocarcinoma. Frontiers in Oncology 9, 541

15. Hassan A, Iqbal T, Tahir MB, Afsheen S (2019): A review on copper vanadate-based nanostructures for photocatalysis energy production. International Journal of Energy Research 43, 9-28

16. Hernandez JE, Edyvean RGJ (2018): Toxicity and biodegradability of caffeic acid in anaerobic digesting sludge. Water SA 44, 27-36

17. Ibrahim S, Bonnet P, Sarakha M, Caperaa C, Monier G, Bousquet A (2020): Tailoring the structural and optical properties of bismuth oxide films deposited by reactive magnetron sputtering for photocatalytic application. Materials Chemistry and Physics 243, 122580

18. Iwahashi H (2015): Chapter 88 - Inhibitory Effects of Caffeic Acid on Free-Radical Formation. In: Preedy VR (Editor), Coffee in Health and Disease Prevention. Academic Press, San Diego, pp. 803811

19. Khulbe KC, Matsuura T (2018): Removal of heavy metals and pollutants by membrane adsorption techniques. Applied Water Science 8, 19

20. Khuwijitjaru P, Suaylam B, Adachi S (2014): Degradation of Caffeic Acid in Subcritical Water and Online HPLC-DPPH Assay of Degradation Products. Journal of Agricultural and Food Chemistry 62, 


\section{5-1949}

21. Le Person A, Lacoste A-S, Cornard J-P (2013): Photo-degradation of trans-caffeic acid in aqueous solution and influence of complexation by metal ions. Journal of Photochemistry and Photobiology A: Chemistry 265, 10-19

22. Lee SH, Kim SS (2019): A New Hollow-Fiber Adsorbent Material for Removing Arsenic from Groundwater. Journal of Chemistry 2019, 2715093

23. López R, Gómez R, Llanos ME (2009): Photophysical and photocatalytic properties of nanosized copper-doped titania sol-gel catalysts. Catalysis Today $148,103-108$

24. Magnani C, Isaac VLB, Correa MA, Salgado HRN (2014): Caffeic acid: a review of its potential use in medications and cosmetics. Analytical Methods 6, 3203-3210

25. Medina I, Undeland I, Larsson K, Storrø I, Rustad T, Jacobsen C, Kristinová V, Gallardo JM (2012): Activity of caffeic acid in different fish lipid matrices: A review. Food Chemistry 131, 730-740

26. Monfort O, Plesch G (2018): Bismuth vanadate-based semiconductor photocatalysts: a short critical review on the efficiency and the mechanism of photodegradation of organic pollutants.

Environmental Science and Pollution Research 25, 19362-19379

27. Ozturk G, Gini_ Z, Akyol S, Erden G, Gurel A, Akyol O (2012): The anticancer mechanism of caffeic acid phenethyl ester (CAPE): review of melanomas, lung and prostate cancers. European review for medical and pharmacological sciences 16 15, 2064-8

28. Pawar M, Topcu Sendoğdular S, Gouma P (2018): A Brief Overview of TiO<sub>2</sub> Photocatalyst for Organic Dye Remediation: Case Study of Reaction Mechanisms Involved in CeTiO $<$ sub $>2<$ /sub $>$ Photocatalysts System. Journal of Nanomaterials 2018, 5953609

29. Rao F, Zhu G, Hojamberdiev M, Zhang W, Li S, Gao J, Zhang F, Huang Y, Huang Y (2019): Uniform Zn2+-Doped BiOI Microspheres Assembled by Ultrathin Nanosheets with Tunable Oxygen Vacancies for Super-Stable Removal of NO. The Journal of Physical Chemistry C 123, 16268-16280

30. Salehi M, Soleimani f, Gholizadeh A (2017): Hydrothermal synthesis, structural and catalytic studies of $\mathrm{CuBi} 2 \mathrm{O} 4$ nanoparticles. Journal of Nanoanalysis

31. Sasidharan V, Sachan D, Chauhan D, Talreja N, Ashfaq M (2021): Three-dimensional (3D) polymermetal-carbon framework for efficient removal of chemical and biological contaminants. Scientific Reports 11, 7708

32. Sharma G, Zhao Z, Sarker P, Nail BA, Wang J, Huda MN, Osterloh FE (2016): Electronic structure, photovoltage, and photocatalytic hydrogen evolution with p-CuBi2O4 nanocrystals. Journal of Materials Chemistry A 4, 2936-2942

33. Silva CG, Bouizi Y, Fornés V, García H (2009): Layered Double Hydroxides as Highly Efficient Photocatalysts for Visible Light Oxygen Generation from Water. Journal of the American Chemical Society $131,13833-13839$

34. Slamet, Nasution HW, Purnama E, Kosela S, Gunlazuardi J (2005): Photocatalytic reduction of CO2 on copper-doped Titania catalysts prepared by improved-impregnation method. Catalysis Communications 6, 313-319 
35. Subbarao EC (1962): Crystal Chemistry of Mixed Bismuth Oxides with Layer-Type Structure. Journal of the American Ceramic Society 45, 166-169

36. Talreja N, Kumar D, Verma N (2014): Removal of hexavalent chromium from water using Fe-grown carbon nanofibers containing porous carbon microbeads. Journal of Water Process Engineering 3 , 34-45

37. Talreja N, Afreen S, Ashfaq M, Chauhan D, Mera AC, Rodríguez CA, Mangalaraja RV (2021a): Bimetal ( $\mathrm{Fe} / \mathrm{Zn}$ ) doped $\mathrm{BiOl}$ photocatalyst: An effective photodegradation of tetracycline and bacteria. Chemosphere 280, 130803

38. Talreja N, Ashfaq M, Chauhan D, Mera AC, Rodríguez CA (2021b): Strategic Doping Approach of the Fe-BiOI Microstructure: An Improved Photodegradation Efficiency of Tetracycline. ACS Omega 6, $1575-1583$

39. Venditti F, Cuomo F, Ceglie A, Avino P, Russo MV, Lopez F (2015): Visible Light Caffeic Acid Degradation by Carbon-Doped Titanium Dioxide. Langmuir 31, 3627-3634

40. Villegas LGC, Mashhadi N, Chen M, Mukherjee D, Taylor KE, Biswas N (2016): A Short Review of Techniques for Phenol Removal from Wastewater. Current Pollution Reports 2, 157-167

41. Yáñez E, Santander P, Contreras D, Yáñez J, Cornejo L, Mansilla HD (2016): Homogeneous and heterogeneous degradation of caffeic acid using photocatalysis driven by UVA and solar light. $J$ Environ Sci Health A Tox Hazard Subst Environ Eng 51, 78-85

42. Yoong LS, Chong FK, Dutta BK (2009): Development of copper-doped TiO2 photocatalyst for hydrogen production under visible light. Energy 34, 1652-1661

43. Yuvaraja G, Prasad C, Vijaya Y, Subbaiah MV (2018): Application of ZnO nanorods as an adsorbent material for the removal of As(III) from aqueous solution: kinetics, isotherms and thermodynamic studies. International Journal of Industrial Chemistry 9, 17-25

44. Zhao H, Tian F, Wang R, Chen R (2014): A Review on Bismuth-Related Nanomaterials for Photocatalysis. Reviews in Advanced Sciences and Engineering 3, 3-27

45. Zheng X, Yuan J, Shen J, Liang J, Che J, Tang B, He G, Chen H (2019): A carnation-like $\mathrm{rGO} / \mathrm{Bi2O} 2 \mathrm{CO} 3 / \mathrm{BiOCl}$ composite: efficient photocatalyst for the degradation of ciprofloxacin. Journal of Materials Science: Materials in Electronics 30, 5986-5994

\section{Figures}



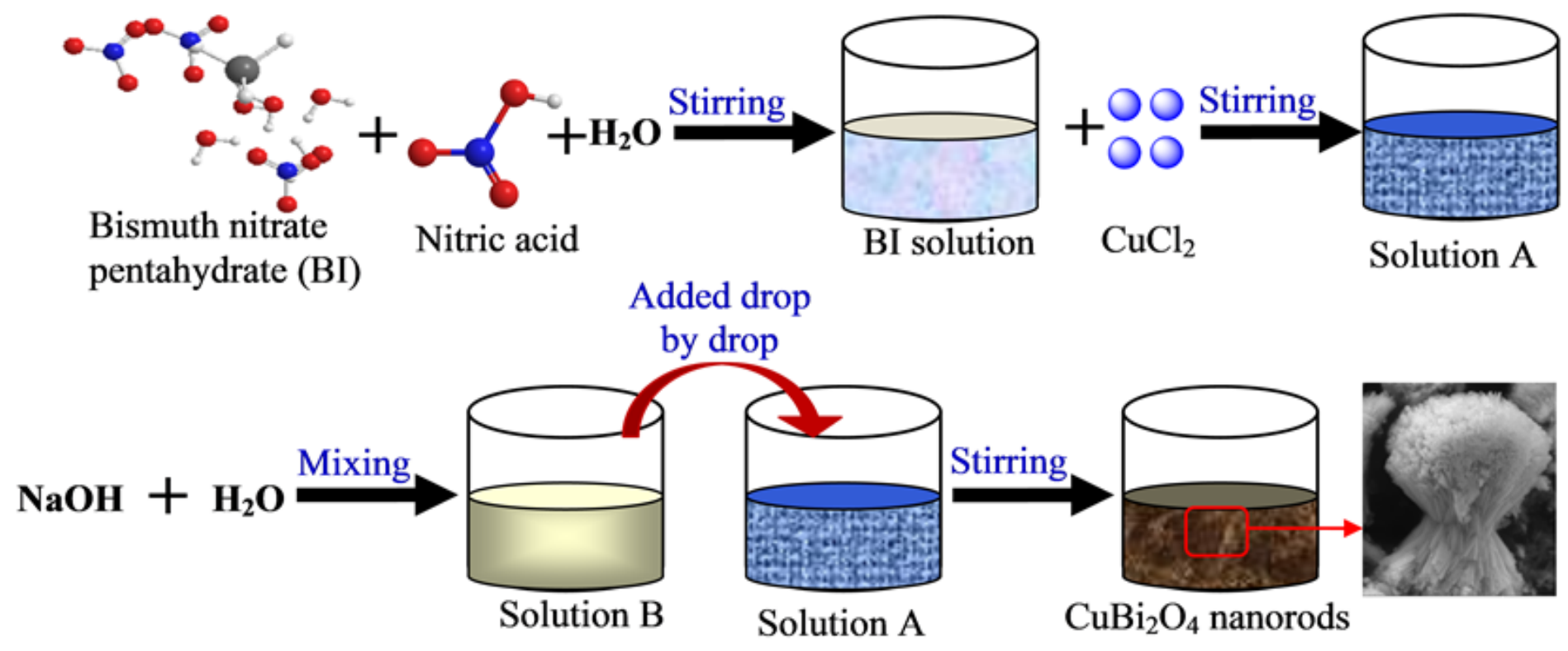

Figure 1

Schematic representation of the synthesis of $\mathrm{CuBi}_{2} \mathrm{O}_{4}$ nanorods. 


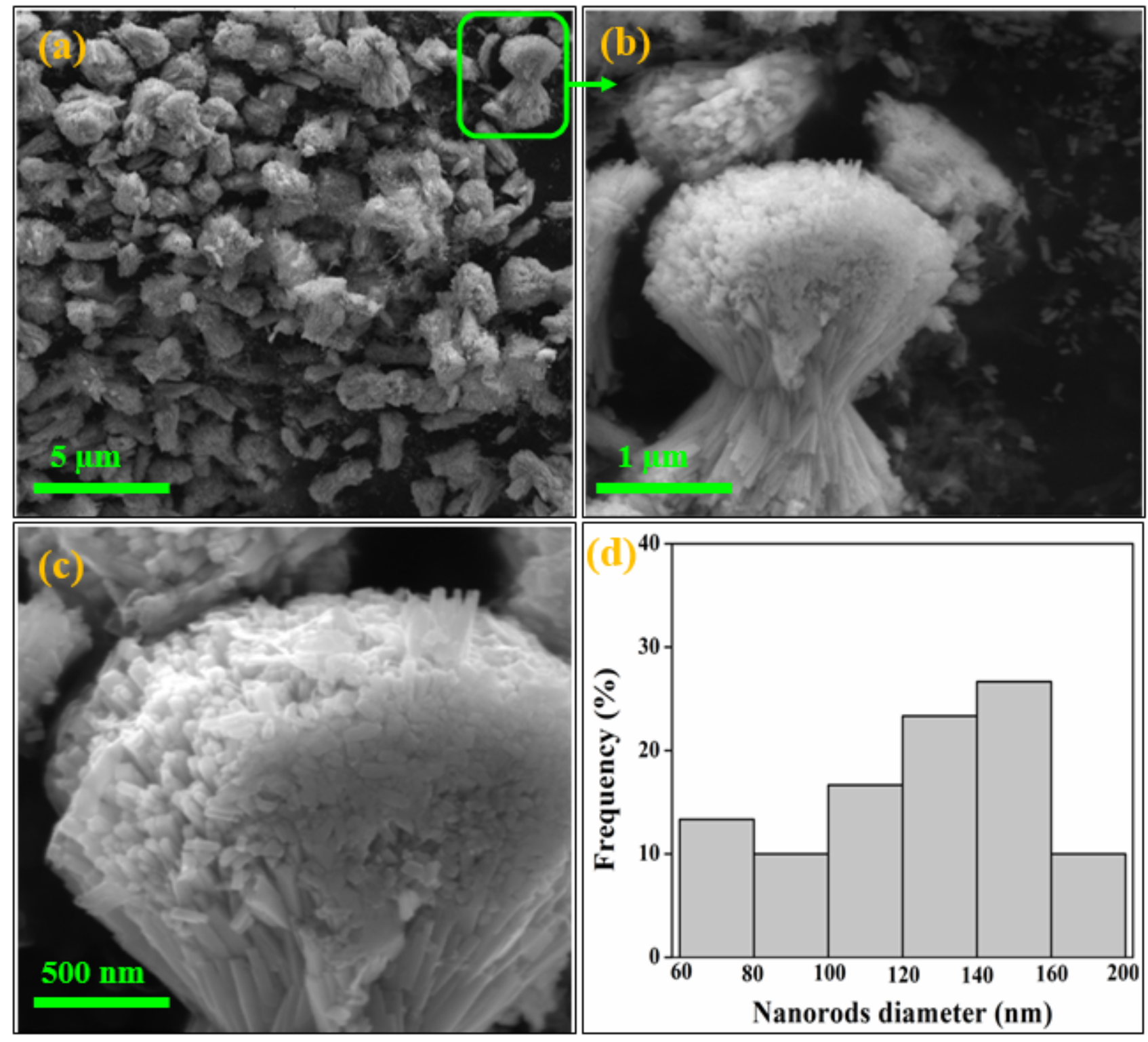

Figure 2

SEM images and nanorods diameter or size distribution plot of synthesized $\mathrm{CuBi}_{2} \mathrm{O}_{4}$ nanorods based photocatalyst material. (a-c). SEM images of $\mathrm{CuBi}_{2} \mathrm{O}_{4}$ nanorods, and (d). nanorods diameter or size distribution plot. 


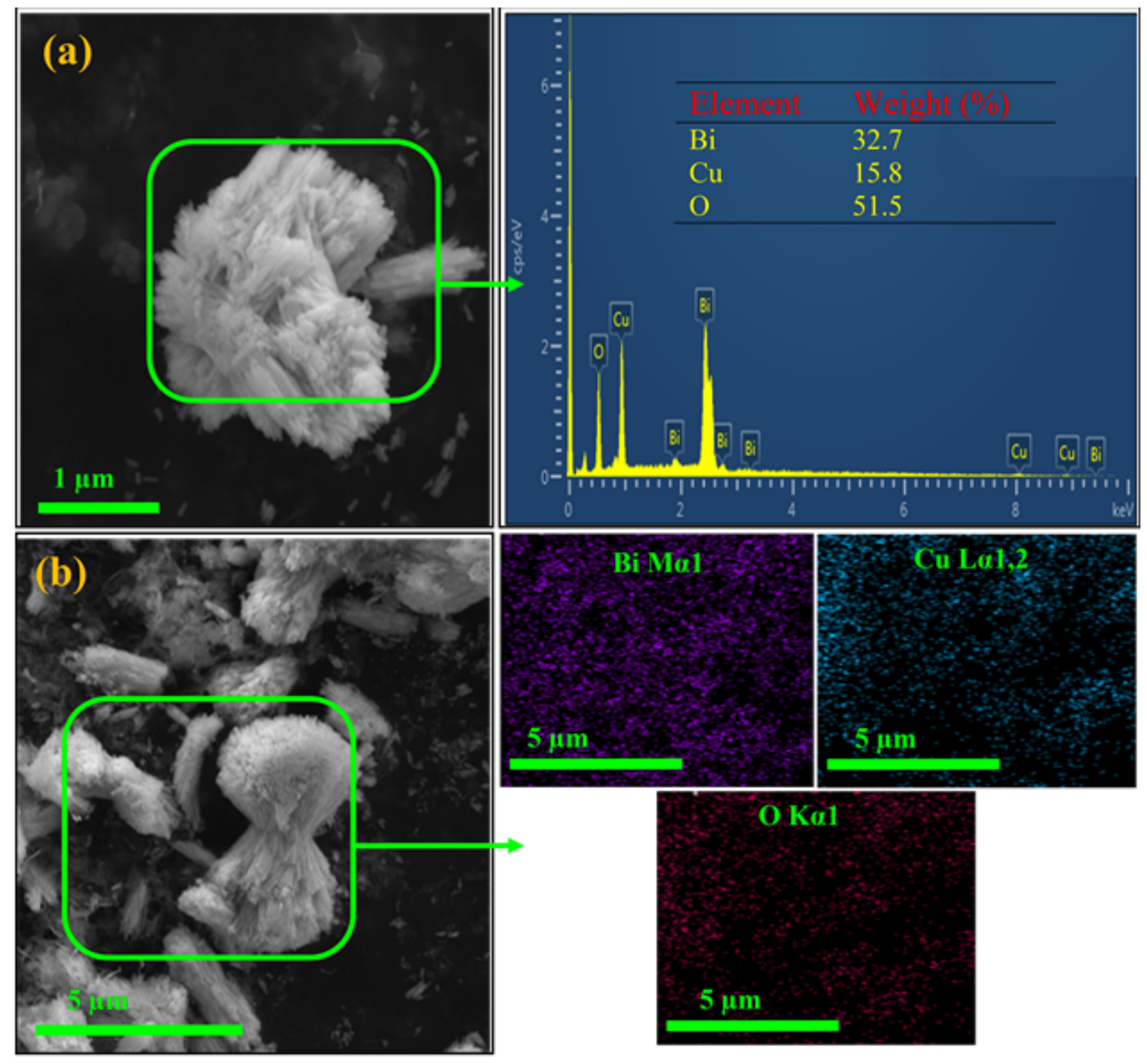

Figure 3

Elemental analysis and mapping of the synthesized $\mathrm{CuBi}_{2} \mathrm{O}_{4}$ nanorods-based photocatalyst material. (a). Elemental analysis, and (b). Elemental mapping. 


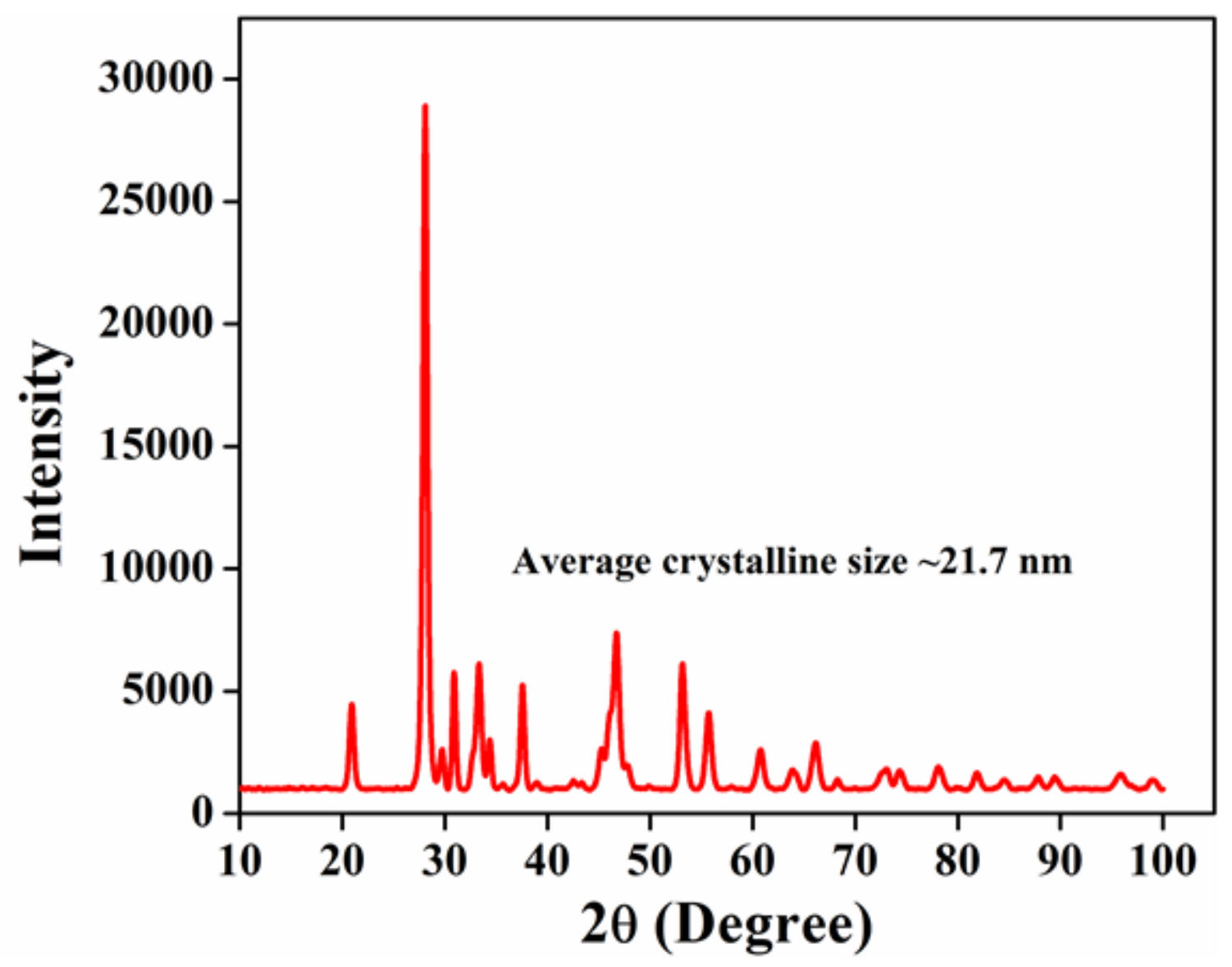

Figure 4

XRD spectrum of the $\mathrm{CuBi}_{2} \mathrm{O}_{4}$ nanorods based photocatalytic material. 


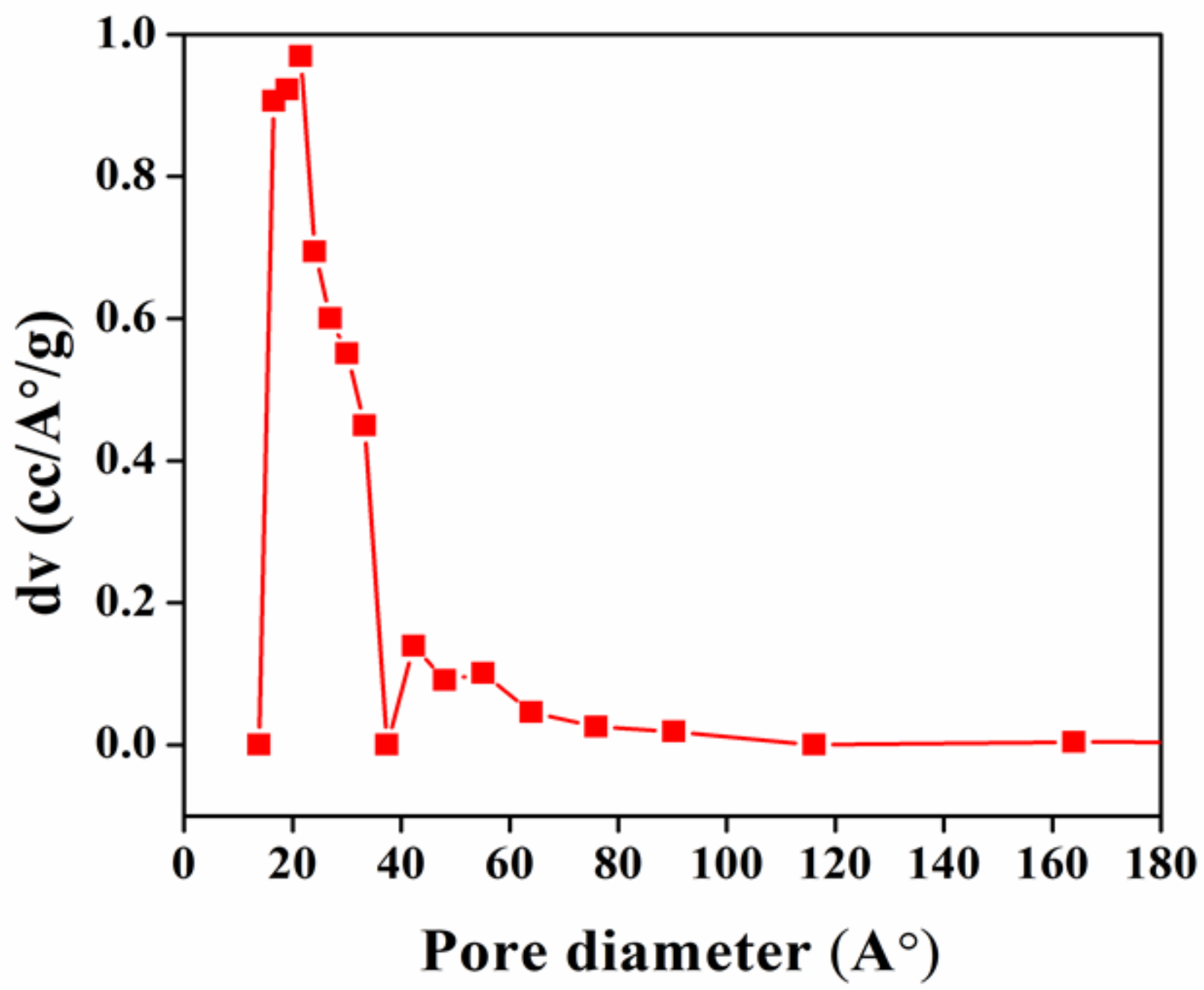

Figure 5

Pore size distribution (PSD) of the $\mathrm{CuBi}_{2} \mathrm{O}_{4}$ nanorods. 


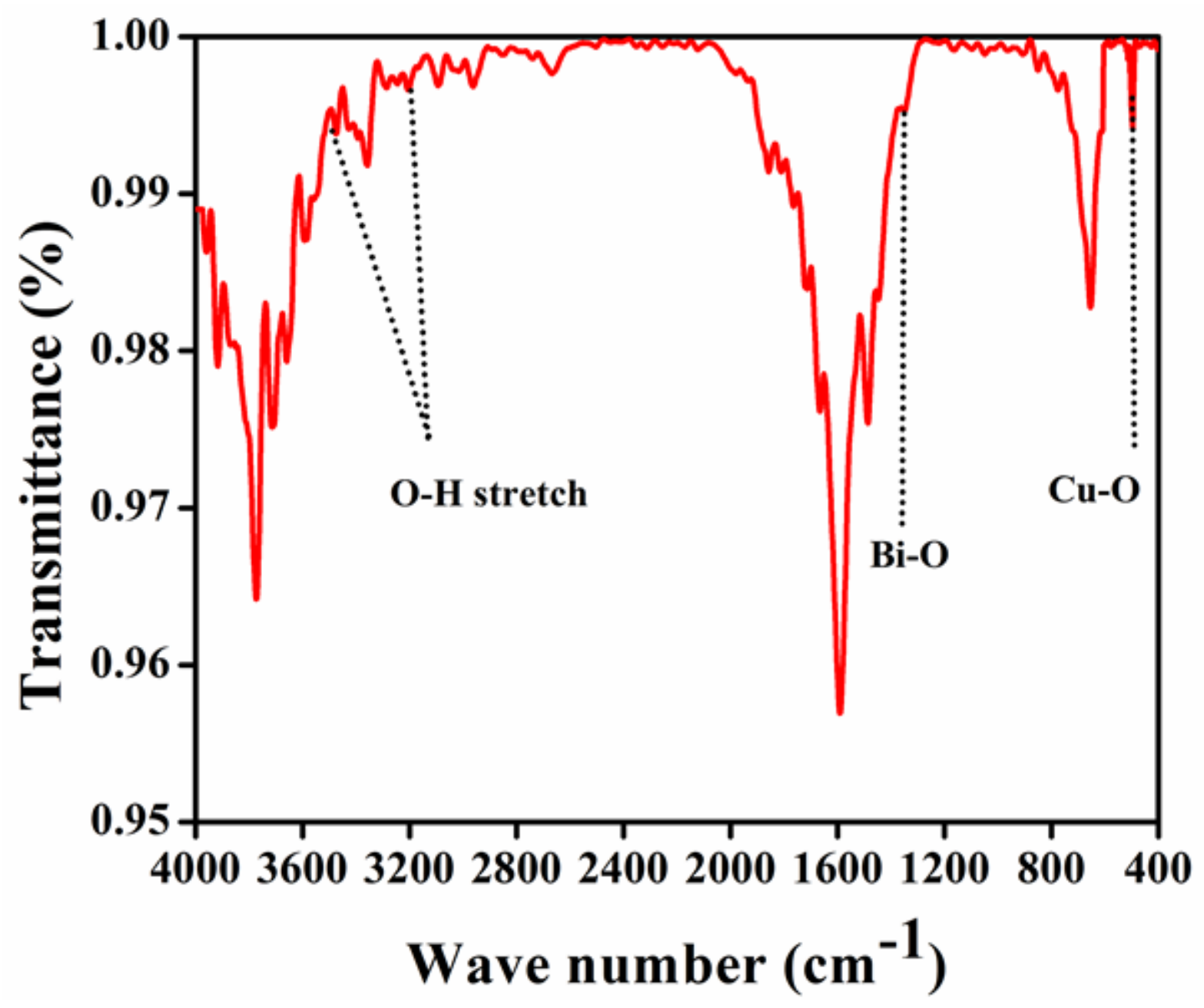

Figure 6

FT-IR spectrum of $\mathrm{CuBi}_{2} \mathrm{O}_{4}$ nanorods based photocatalytic material. 

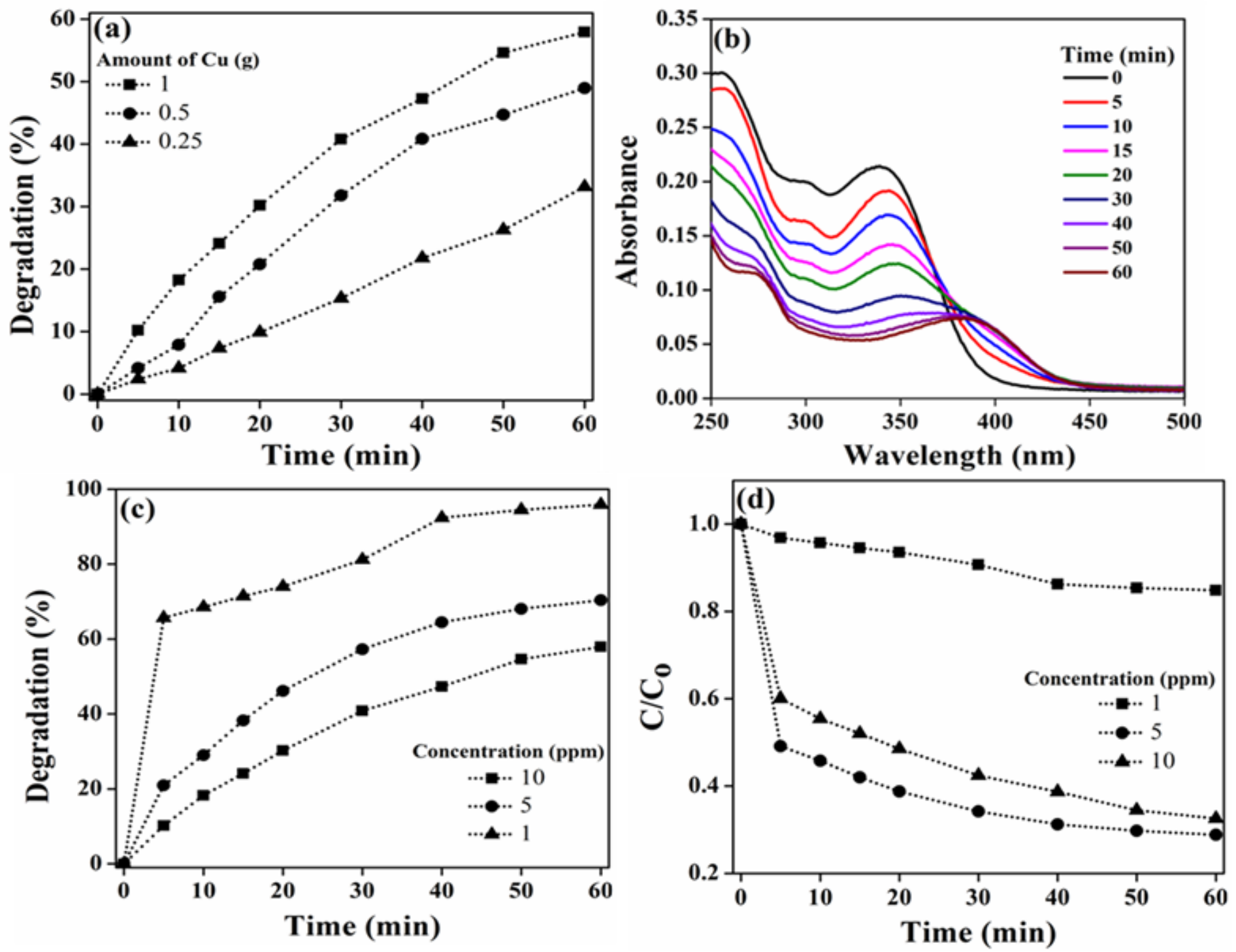

Figure 7

Photocatalytic degradation (\%) of $\mathrm{CA}$ compound using different $\mathrm{CuBi}_{2} \mathrm{O}_{4}$ nanorods. (a) Degradation (\%) of $\mathrm{CA}$ using $\mathrm{CuBi}_{2} \mathrm{O}_{4}$ nanorods with varying amounts of $\mathrm{Cu}$ metal $\left(1.0,0.50\right.$, and $0.25 \mathrm{~g}$ ) within $\mathrm{CuBi}_{2} \mathrm{O}_{4}$, (b) UV-spectra of $\mathrm{CA}$ using $\mathrm{CuBi}_{2} \mathrm{O}_{4}$ nanorods at a different time interval, (c) Degradation (\%) of $\mathrm{CA}$ using $\mathrm{CuBi}_{2} \mathrm{O}_{4}$ at different concentration $(1,5$, and $10 \mathrm{mg} / \mathrm{L})$, and (d) Degradation as a function of time. 

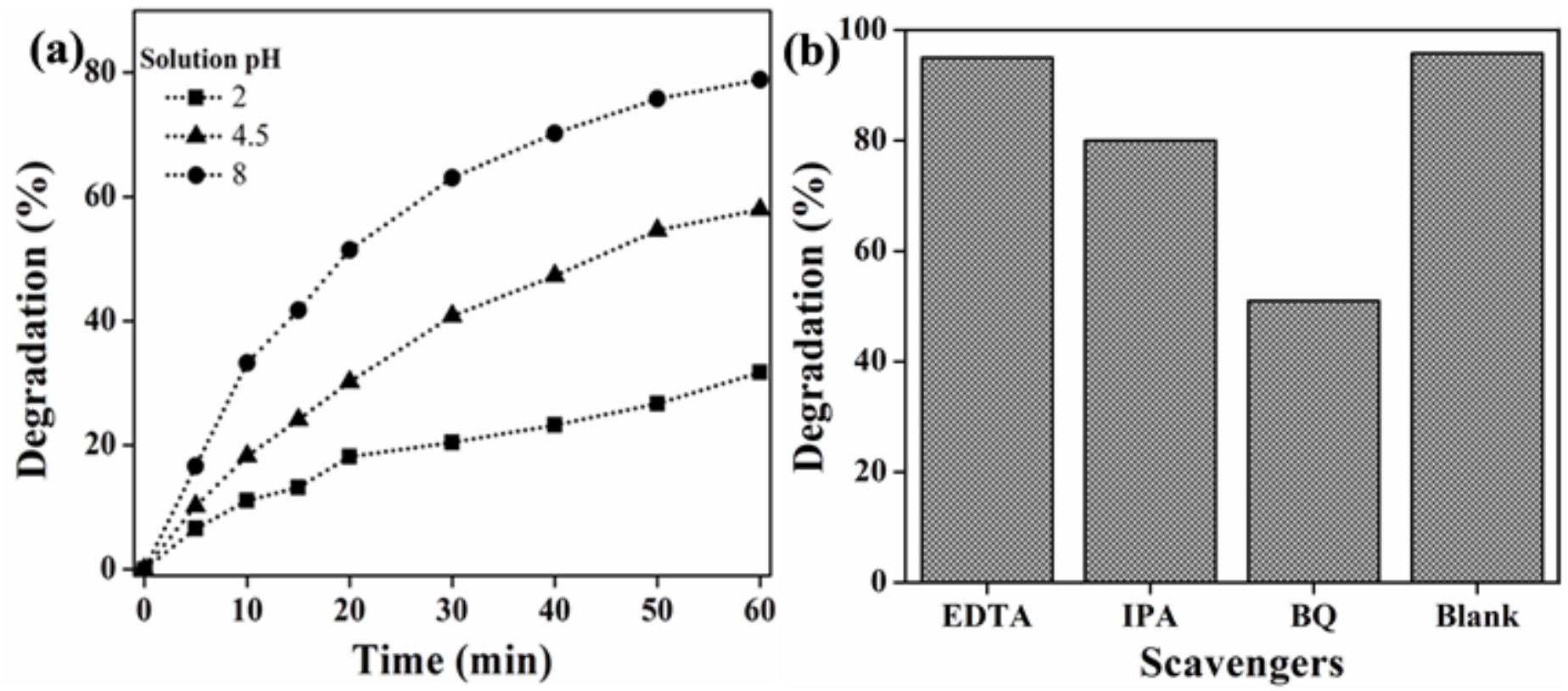

Figure 8

(a) Degradation (\%) of CA at different $\mathrm{pH}(2-8)$ of the CA solution, and (b) scavenger effects on $\mathrm{CA}$ degradation.

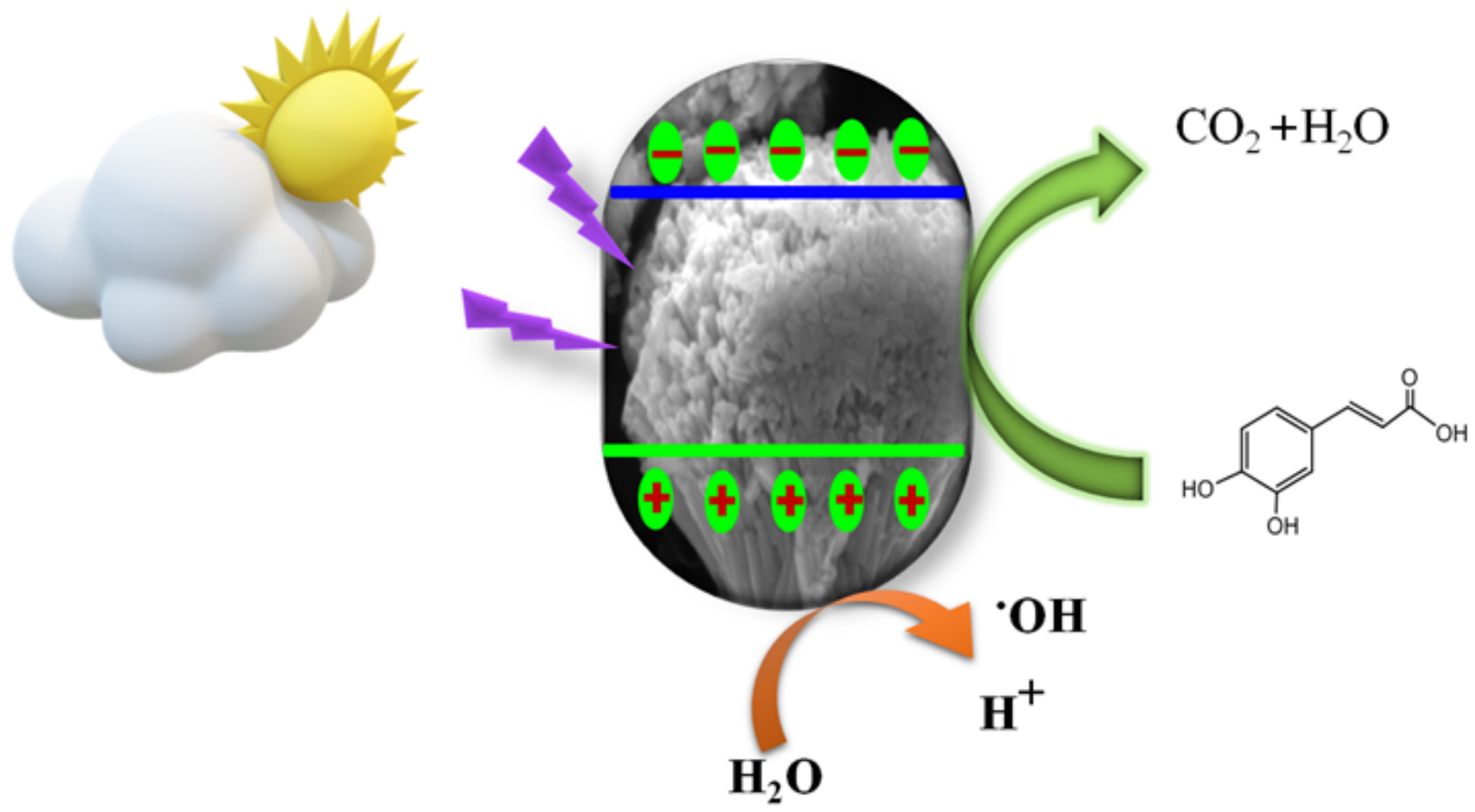

Figure 9

A plausible mechanism of the CA degradation. 